ДВНЗ “Тернопільський державний медичний університет імені I. Я. Горбачевського МОЗ України”

\title{
НАВЧАЛЬНО-МЕТОДИЧНЕ ТА МАТЕРІАЛЬНО-ТЕХНІЧНЕ ЗАБЕЗПЕЧЕННЯ ОСВІТНЬОГО ПРОЦЕСУ НА КАФЕДРІ МЕДИЧНОЇ БІОХІМІЇ
}

\author{
M. M. Korda, H. H. Shershun, M. I. Kulitska, S. R. Pidruchna, \\ O. I. Ostrivka, O. Z. Yaremchuk \\ I. Horbachevsky Ternopil State Medical University

\section{METHODOLOGICAL AND LOGISTIC SUPPORT OF THE LEARNING PROCESS AT THE DEPARTMENT OF MEDICAL BIOCHEMISTRY}

\begin{abstract}
Мета роботи - обгрунтувати способи забезпечення оптимального засвоєння студентами матеріалу з біохімії як основи клініко-лабораторної діагностики.

Основна частина. У статті відображена концепція навчально-методичного та матеріально-технічного забезпечення навчання студентів на кафедрі медичної біохімії у світлі сучасних вимог інтеграції в європейські та світові освітні структури. Насамперед це практично-орієнтоване навчання, що дозволяє досягти розвитку клінічного мислення на основі констеляції біохімічних показників. Біохімічні підходи посідають чільне місце в діагностичному процесі, бо лише вони відображають молекулярні механізми розвитку патологічного процесу.

Не менш важливою умовою навчання $є$ напрямок, який визначає професійну компетентність майбутніх фахівців - базовий рівень, прагнення до подальшої самоосвіти, аналітичне мислення, узагальнення наявної інформації, уміння прогнозувати вирішувати нештатні ситуації тощо. Нарешті, сучасне навчання студентів неможливе без впровадження таких інноваційних технологій, як: комп’ютерні віртуальні програми-тренінги з біохімії, що моделюють різні метаболічні шляхи, процеси чи алгоритми лабораторних досліджень, відеофільми, мультимедійні лекції, технічне обладнання робочих місць студентів у навчальних лабораторіях.

Особливих вимог потребують уміння студентів виконувати й інтерпретувати матрикульні біохімічні дослідження, які використовуються в діагностиці найпоширеніших хвороб. Клініко-лабораторна ерудиція особливо важлива в практиці кожного сучасного лікаря, і глибокі знання біохімічних процесів повинні займати чільне місце в його активі для вирішення професійних обов’язків.

Висновок. Викладання біохімії студентам-медикам повинно бути практично-орієнтованим, компетентнісним, мати мотиваційне спрямування, що забезпечується належною методичною базою, широким впровадженням інноваційних технологій, вдосконаленням бази клініко-біохімічних тестових завдань, високим рівнем міжкафедральної інтеграції суміжних дисциплін.
\end{abstract}

Ключові слова: практично-орієнтоване навчання; компетентність; інноваційні технології; біохімічна діагностика.

The aim of the study - to substantiate optimal means for ensuring knowledge acquisition in biochemistry as fundamentals of clinical and laboratory diagnostics.

The main body. The concept of methodological and logistic support for students' learning at the Department of Medical Biochemistry in terms of up-to-date requirements for integration into European and world educational framework is presented in the article. First of all, it is a practice-oriented training that allows development of medical critical thinking based on constellation of chemistry value. Biochemical approaches are very important for diagnosis, because only they reveal the molecular pathogenesis.

Field of study is also essential; it defines the professional competence of rising professionals: basic education degree, desire to further self-education, analytical thinking, deduction of available information, ability to predict and deal with challenges at emergency situations and so on. Finally, current student education is impossible without the introduction of innovative technology: computer virtual training programs in biochemistry that simulate various metabolic fates, courses and algorithms of laboratory tests, videos, multimedia lectures, technical equipment for students' working area in university laboratories.

(c) М. М. Корда, Г. Г. Шершун, М. І. Куліцька та ін. 
Students' skills in performing and interpreting matriculation biochemical screen used for diagnosis of the most widespread diseases are of particular requirements. Clinical and laboratory erudition is especially important in practice of each physician in our day, so their comprehensive expertise in biochemical processes is crucial for exercise of the profession.

Conclusion. Biochemistry teaching for medical students should be practice-oriented, competency based, and of motivational approach to provide appropriate methodological background, widespread introduction of innovative technologies, improved clinical and biochemical tests, developed interdepartmental integration of related subjects.

Key words: practice-oriented training; competency; innovative technologies; biochemical diagnostics.

Вступ. На сучасному етапі розвитку біологічних наук незаперечним є факт, що тільки шляхом розкриття хімічних, фізико-хімічних, субклітинних, субмолекулярних закономірностей функціонування живих систем можливе опанування внутрішніх механізмів патогенезу найпоширеніших хвороб людини - імунодефіцитних, онкологічних, серцево-судинних, генетичних тощо. Відповідно до цього, сучасна біохімія все більшою мірою набуває значення як теоретична основа медицини, і її викладання у ВНЗ медичного профілю створює підвалини для подальшого вивчення загальної патології та клінічних предметів, формування світогляду лікаря [5].

Мета роботи - обгрунтувати способи забезпечення оптимального засвоєння студентами матеріалу з біохімії як основи клініко-лабораторної діагностики.

Основна частина. Вивчення біохімії людини здійснюється студентами медичного, стоматологічного, медико-профілактичного факультетів протягом 2-го року навчання; фармацевтичного факультету та зі спеціальності “Біологія” - протягом 2-3-го року і студентами 1-го курсу медсестер-бакалаврів.

Викладання біологічної хімії спрямоване на активацію пізнавальної діяльності студентів, оволодіння практичними навичками, розвиток клінічного мислення на основі констеляції біохімічних показників. Принципи практично-орієнтованого навчання сприяють покращенню засвоєння навчального матеріалу, опануванню вмінь та навичок біохімічних досліджень, дозволяють оволодіти знаннями про молекулярні механізми як фізіологічних процесів організму, так і їх розладів при патології. Значення глибокого розуміння закономірностей перебігу біохімічних процесів в організмі людини постійно зростає у зв'язку з тією обставиною, що біохімічні підходи та методи посідають чільне місце в діагностичному процесі, контролі за перебігом хвороби та ефективністю лікування. Клініколабораторна ерудиція особливо важлива в практиці лікаря загальної практики - сімейної медицини. Застосування практично-орієнтованого навчання сприяє підвищенню мотивації студентів до майбутнього професійного розвитку. Різноплановість у підходах до навчального процесу студентів визначає професійну компетентність майбутніх фахівців. А це означає: базовий рівень освіти, прагнення до подальшої самоосвіти, творче і аналітичне мислення, цілеспрямований пошук, збір та узагальнення необхідної інформації, уміння прогнозувати ситуації, прагнення до досконалості, відстоювання власних позицій, компетентний підхід до нештатних клінічних ситуацій тощо [1, 2, 4, 6].

Традиційними видами навчального процесу, згідно $з$ академічним планом, є: лекції, практичні заняття, самостійна робота. Лекції супроводжуються демонстрацією схем, таблиць, малюнків, графіків, відеофільмів з допомогою мультимедійної техніки; така наочність підвищує рівень засвоєння студентами лекційного матеріалу. Зручними орієнтирами для цього є також презентації лекцій, матеріали для підготовки до лекцій, відображені на веб-сторінці кафедри.

Практична частина заняття передбачає лабораторні дослідження - проведення якісних і кількісних реакцій з біологічними об’ єктами (кров, слина, шлунковий сік, витяжки $з$ тканин, фармацевтичні препарати тощо), оцінку отриманих показників, відповідні записи в протоколах. В загальному підсумку основний акцент спрямований на клінічне значення отриманих результатів. Найінформативніші клінічні показники потребують високого рівня практичних навичок студентів (матрикул). На медичному факультеті пропонується 12 показників (глюкоза, холестерол, загальний білок, фракції білків, білірубін крові; діастаза, глюкоза, ацетон, сечовина, сечова кислота, білок, креатинін сечі). Стоматологічному і фармацевтичному факультетам пропонується по 5 показників (глюкоза, білок у крові і сечі, $\alpha$-амілаза слини - стоматологічний; глюкоза, білок у крові і сечі, ацетон сечі - фармацевтичний). Незасвоєння хоча б одного з матрикулів кваліфікується як невиконання навчальної програми.

Вважаємо невиправданою практику проведення занять за цикловою системою, яка пропонувалась 
раніше і була апробована на кафедрі в попередні роки. По-перше, лекційний матеріал не може одночасно охоплювати теми кількох різних циклів, виклад біохімії вимагає стрункої логічної послідовності. Практичні заняття проводяться водночас за 3-4 циклами, тому більшість студентів позбавлена можливості користуватись лекційним матеріалом для підготовки до занять. По-друге, для викладачів біохімії неприйнятна вузька спеціалізація (що вимагала циклова система), оскільки метаболічні процеси в організмі настільки тісно пов’язані, взаємозалежні і взаємообумовлені, що навіть грунтовне вивчення лише одного розділу це однобокий, непрофесійний підхід, він звужує інтереси викладача.

Практичне заняття з біохімії, крім лабораторної частини, включає і семінарську частину - загальну співбесіду зі студентами, в ході якої обговорюються ключові питання теми, вирішуються ситуаційні завдання, тести ліцензійного іспиту “Крок-1”, перегляд віртуальних програм. За результатами всіх видів діяльності кожен студент отримує загальну оцінку. Постійна перевірка знань привчає студентів систематично працювати, цілеспрямовано і наполегливо прагнути продуктивного засвоєння знань, розвитку пізнавальної діяльності, наукової ерудиції. Кафедра забезпечує всіма необхідними методичними і технічними засобами для підготовки студентів до лекцій, практичних занять, самостійної роботи, опрацювання матрикульних показників, такими, як: методичні вказівки, презентації лекцій, матеріали підготовки до лекцій і практичних занять, віртуальні програми-тренінги, банк тестових завдань, найновіші підручники і практичні посібники, видані кафедрою, комп’ютери, відеосистеми, консультативна допомога чергових викладачів. Інтерактивні інноваційні технології в навчальному процесі - це збільшення швидкості і міцності сприйняття масиву знань, розвиток творчості, навичок проведення логічних узагальнень, оптимальних рішень. Це приносить вищі навчальні результати порівняно з традиційними підходами [4, 7].

Сучасні інноваційні технології дозволяють впровадити в навчальний процес не лише традиційні біохімічні експерименти в пробірці, але й комп’ютерне моделювання методів біохімічного аналізу, складних біохімічних процесів (інтеграція специфічних і загальних шляхів катаболізму; тканинний і внутрішньосудинний метаболізм ліпопротеїнів; обмін жовчних пігментів у нормі і при жовтяницях; роль нирок у регуляції кров’яного тиску; молекулярний механізм скорочення і розслаблення м'язів; обмін глікогену печінки і м’язів; знешкоджувальна функція печінки тощо). Візуалізація складних процесів покращує їх сприйняття, є додатковою мотивацією до навчальної діяльності [1].

На перший погляд, цих заходів достатньо, якщо орієнтуватись на студентів 3 не надто високими амбіціями в досягненні мети навчання у ВНЗ. Але таких меншість, тому наше пріоритетне завдання подальше вдосконалення підходів до пізнавальної діяльності студентів, зокрема прагнути:

- включати в лекційний курс новітні досягнення біохімічної науки, практикувати читання кількох проблемних лекцій з найактуальніших питань сучасної біохімії і практичної медицини, зокрема проблем нанотехнологій у медицині;

- досвідченим, високопрофесійним викладачам проводити майстер-класи для молодих викладачів кафедри, використовувати практику проведення відкритих занять з наступним обговоренням;

- досягти повного матеріального забезпечення кожного практичного заняття, обладнання робочих місць для індивідуального (що є оптимальним) виконання студентами лабораторних робіт (реактиви, посуд, вимірювальні прилади тощо); максимально використовувати технічні засоби (інтерактивні дошки, відеосистеми тощо);

- досягти високого рівня міжкафедральної інтеграції суміжних дисциплін, що дозволяє втілювати об’єктивно-орієнтоване навчання і спадкоємність наукових положень [3]:

- популяризувати і впроваджувати в навчальний процес наукові здобутки кафедри, заохочувати й активно залучати студентів до наукової роботи, участі в олімпіадах, конференціях, симпозіумах;

- продовжувати роботу по оновленню бази клініко-біохімічних ситуаційних задач, тестів, розв’язання яких вимагає аналізу можливих варіантів та формулювання логічного висновку, зміщення акценту з теоретичних підвалин біохімії на практичну медицину;

- викладачам доцільно періодично ознайомлюватись 3 біохімічними дослідженнями в лабораторіях лікувальних закладів для запозичення i впровадження в навчальний процес уніфікованих лабораторних аналізів;

- ширше інтегрувати традиційні технології навчання з інноваційними, що забезпечують формування майбутнього фахівця достойного рівня компетентності; 


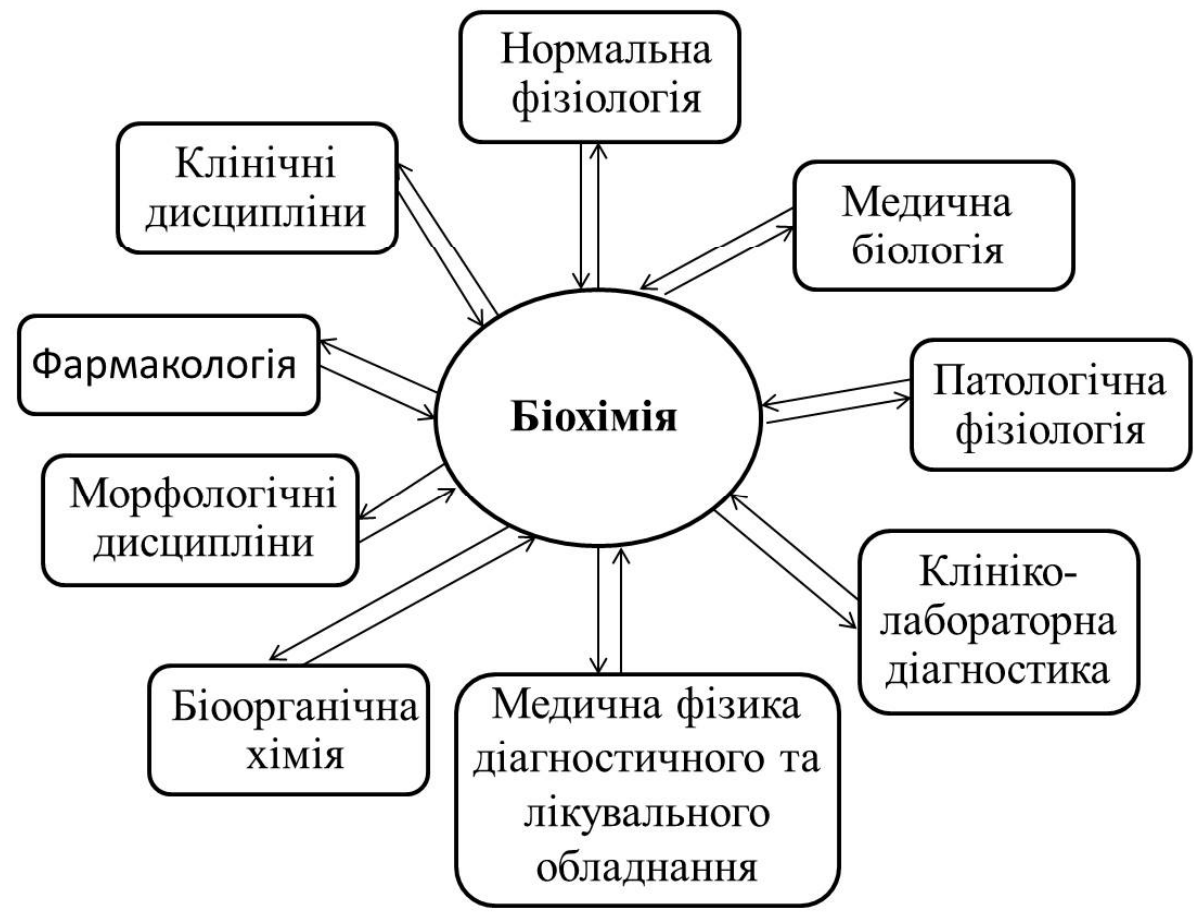

- налагоджувати тіснішу інтеграцію з кафедрою клініко-лабораторної діагностики;

- продовжувати розробку і впровадження в навчальний процес комп’ютерних програм-тренінгів з біохімії, що моделюють метаболічні шляхи, процеси чи алгоритми лабораторних досліджень, що полегшує засвоєння матеріалу.

Висновки. 1. Викладання біохімії студентам-медикам повинно мати практично-орієнтовану систему, що передбачає вивчення теоретичних положень i їх клінічне осмислення, обгрунтування біохімічних показників у діагностичному процесі.

2. Успішне оволодіння матеріалу з біохімії можливе за умови запровадження інноваційних техно- логій, які формують компетентність, прогресивність, професіоналізм медика в сучасних умовах.

3. Вдосконалення, розширення бази клініко-біохімічних ситуаційних завдань, програм-тренінгів, що вимагають логічного мислення, впровадження їх у навчальний процес $є$ запорукою кращого засвоєння студентами програми, імплементації їх знань у клініці.

4. Матрикули практичних навичок повинні відображати найважливіші біохімічні показники, які використовуються в діагностиці хвороб печінки, серця, нирок, підшлункової залози, сполучної тканини, генетичних ферментопатій.

Х. В. Подковко // Медична освіта. - 2016. - № 1. C. 41-43.

5. Проблема розвитку критичного мислення у студентів-медиків / І. В. Корда, С. М. Геряк, Н. В. Петренко, І. Я. Кузів // Медична освіта. - 2014. - № 3. - С. 83-84.

6. Філоненко М. М. Проектування навчальних занять у системі вищої медичної освіти на основі компетентнісного підходу / М. М. Філоненко // Медична освіта. - 2016. - № 1. - С. 47-49.

7. Шершун Г. Г. Досвід розробки і впровадження віртуальних програм з біохімії в навчальний процес / Г. Г. Шершун, М. М. Корда // Медична освіта. - 2014. № 3. - C. 155-157. 


\section{References}

1. Herush, I.V., Hryhorieva, N.P., \& Davydova, N.V. (2016). Suchasni pidkhody do vykladannia bioorhanichnoi i biolohichnoi khimii v medychnykh VNZ [Current approaches to teaching bioorganic and biological chemistry at the medical university]. Medychna ta klinichna khimiia Medical and Clinical Chemistry, 4, 114-117 [in Ukrainian].

2. Zahrychuk, H.Ya, Martseniuk, V.P., \& Mysula, I.R. (2013). Pidhotovka fakhivtsiv u vyshchykh navchalnykh zakladakh Ukrainy $\mathrm{v}$ suchasnykh umovakh na osnovi kompetentnisnoho pidkhodu [Training in higher education institutions of Ukraine in modern conditions on the competence approach basis]. Medychna osvita - Medical Education, 1, 8-11 [in Ukrainian].

3. Karpets, M.V. (2014). Rol medychnoi khimii u formuvanni studenta-medyka [The role of medical chemistry in the formation of medical student]. Medychna osvita Medical Education, 3, 72-75 [in Ukrainian].

4. Podkovko, Kh.V. (2016). Innovatsiini tekhnolohii navchannia $\mathrm{v}$ konteksti kompetentnisnoho pidkhodu $\mathrm{v}$

Електронна адреса для листування: kulitskam@tdmu.edu.ua osviti [Innovative learning technologies in the context of competence approach in education]. Medychna osvita Medical Education, 1, 41-43 [in Ukrainian].

5. Korda, I.V., Heriak, S.M., Petrenko, N.V., \& Kuziv, I.Ya. (2014). Problema rozvytku krytychnoho myslennia u studentiv-medykiv [The problem of medical students' critical thinking development]. Medychna osvita - Medical Education, 3, 83-84 [in Ukrainian].

6. Filonenko, M.M. Proektuvannia navchalnykh zaniat u systemi vyshchoi medychnoi osvity na osnovi kompetentnisnoho pidkhodu [Learning sessions design in the system of higher medical education on the basis of competence approach]. Medychna osvita - Medical Education, 1, 47-49 [in Ukrainian].

7. Shershun, H.H., \& Korda, M.M. (2014). Dosvid rozrobky i vprovadzhennia virtualnykh prohram z biokhimii $\mathrm{v}$ navchalnyi protses [The experience of development and implementation of virtual programs on biochemistry in the educational process]. Medychna osvita-Medical Education, 3, 155-157 [in Ukrainian].

Отримано 03.04.17 